\title{
Study of childhood renal tumours using a monoclonal antibody to Tamm-Horsfall protein
}

\author{
S KUMAR, * H B MARSDEN, * B JASANI, P KUMAR \\ From the *Christie Hospital, Manchester, and the Department of Pathology, University College of Medicine, \\ Cardiff, Wales
}

SUMMARY A monoclonal antibody to Tamm-Horsfall glycoprotein was used for the immunolocalisation of Tamm-Horsfall protein in formalin fixed, paraffin embedded tissue sections of childhood renal tumours, normal children's kidneys, and human fetal kidneys. The procedure was a dinitrophenyl hapten sandwich staining method. The antibody, diluted 1/100000, gave a very strong and specific staining of the loop of Henle and distal tubules of normal and fetal kidneys. No staining was seen in Wilms' tumour, mesoblastic nephroma, and bone metastasing renal tumour of childhood. In contrast, two of seven renal carcinomas and three of four rhabdoid renal tumours were positive for Tamm-Horsfall protein.

Tamm-Horsfall protein is present in the urine of many placental mammalian species including man. $^{1-12}$ Localisation of Tamm-Horsfall protein in kidney tissue has been undertaken by numerous workers using a variety of techniques such as nonspecific periodic acid Schiff (PAS) staining, indirect immunofluorescence, and immunoperoxidase staining with polyclonal antibodies. The results of these studies are controversial, although most reports tend to agree that Tamm-Horsfall protein is mainly localised in the thick loop of Henle and distal tubules (table 1). Wallace and Nairn ${ }^{8}$ produced two antisera, one of which was against brush border antigen and the other to Tamm-Horsfall protein. With these antisera, Wallace and Nairn found that renal cell carcinomas contained brush border antigen and no Tamm-Horsfall protein, whereas Wilms' tumours were positive for both brush border antigen and Tamm-Horsfall protein antigen. ${ }^{13}$ These results were interpreted to mean that carcinomas arose from proximal tubular epithelium and Wilms' tumours from more primitive metanephric cells. In a previous paper we questioned the conclusion of these findings which were based on the use of polyclonal antibodies. ${ }^{14}$ In this paper we undertook the immunolocalisation of Tamm-Horsfall protein in childhood renal tumours, human fetal kidneys, and normal children's kidneys with a monoclonal antibody to Tamm-Horsfall protein.

Accepted for publication 11 June 1987

\section{Material and methods}

Biopsy specimens fixed in $10 \%$ buffered formalin embedded in paraffin, sectioned at a thickness of 3-5 $\mu \mathrm{m}$ were applied to chrom-gel coated glass slides? Biopsy or necropsy specimens of normal kidneys from children were obtained within 18 hours of death. All of these kidneys were normal on light microscopy. Fetal kidneys were collected soon after therapeutic abortion (14-21 weeks of gestation). Both normal and fetal kidneys were fixed, paraffin embedded, and sectioned using the same procedure as that for tumours. Table 2 gives details of the tissues examined.

Details of the production, characterisation, and use of Tamm-Horsfall protein antibody have been published. ${ }^{11 \text { 15-17 }}$ Anti-Tamm-Horsfall protein monoclonal antibody is an $\operatorname{IgG}_{1}(\kappa)$ antibody and has been characterised using immunofluorescence, immunoperoxidase, and Western blotting techniques. Among the many types of tissue studied, the antibody was confined to kidney sections and showed no cross reactivity against other tissues. ${ }^{11}$ The anti-TammHorsfall protein monoclonal was reactive with intact human Tamm-Horsfall protein (molecular weight 100000 daltons) and an enzyme digested fragment of 80000 daltons. Soluble human Tamm-Horsfall protein completely abolished the binding of an affinity purified anti-Tamm-Horsfall protein monoclonal in an enzyme linked immunosorbent assay (ELISA).

A dinitrophenyl hapten localisation kit was used in the immunoperoxidase staining of all the tissues. The 
Table 1 Summary of studies undertaken for localisation of Tamm-Horsfall glycoprotein in human kidneys

\begin{tabular}{|c|c|c|c|c|c|}
\hline \multicolumn{5}{|c|}{ Detection of Tamm-Horsfall protein in Kidneys } & \multirow[b]{2}{*}{ References } \\
\hline Glomerulus & Loop of Henle & Proximal tubule & Distal tubule & Collecting duct & \\
\hline & & & & + & Hermann (1963) \\
\hline & & + & & & Keutel (1965) \\
\hline & & + & & & Cornelius et al (1965) \\
\hline & + & & + & & Friedmann (1966) \\
\hline & + & & $+(1)$ & & McKenzie and McQueen (1969) \\
\hline & + & & + & + & Pollak and Arbel (1969) \\
\hline & + & & $+(1)$ & & Schenk et al (1971) \\
\hline & + & & $+(1)$ & & Wallace and Nairn (1971) \\
\hline & + & & + & & Hoyer et al (1979) \\
\hline & + & & + & & Sikri et al (1981) \\
\hline & + & & $-(2)$ & & Hennigar (1985) \\
\hline$-(3)$ & + & & $+(4)$ & $-(5)$ & $\begin{array}{l}\text { Kumar et al }(1985) \\
\text { and the present study }\end{array}$ \\
\hline
\end{tabular}

(1) Macula densa stained intensely; (2) staining intensity varied from unreactive to very weakly positive; (3) all glomerular tufts were negative but in some instances a positive reaction was noticed in Bowman's space; (4) macula densa was negative (see note 1); (5) collecting ducts were negative, although in some, casts of Tamm-Horsfall protein antigen were seen.

details of the reagents used and the conditions and rationale for their use are described elsewhere 111819 and in the instructions for the kit. In brief, antiTamm-Horsfall protein mouse monoclonal antibody D2 was diluted $1 / 100000$ using $0.6 \%$ bovine serum albumin (BSA; Sigma) in phosphate buffered saline (PBS; 0.01 M, pH7.2). This was applied to dewaxed and hydrogen peroxide methanol inhibited sections for 30 minutes at room temperature. After three one minute washes in PBS the sections were treated in sequence with sheep antimouse immunoglobulin $(1 / 2000)$ labelled with dinitrophenyl hapten, mouse IgM monoclonal anti-dinitrophenyl hapten bridge reagent $(1 / 2000)$, dinitrophenyl hapten-horseradish peroxidase $(1 / 1000)$, and dinitrophenyl haptenglucose oxidase (100 units/ml), respectively, each for 30 minutes at room temperature (three one minute

Table 2 Localisation of Tamm-Horsfall protein in childhood renal tumours, normal, and fetal kidneys using a monoclonal antibody to Tamm-Horsfall protein

\begin{tabular}{ll}
\hline Source & $\begin{array}{l}\text { Nos positive for } \\
\text { Tamm-Horsfall protein/ } \\
\text { Nos examined }\end{array}$ \\
\hline Renal tumours: & \\
Wilms' & $0 / 12$ \\
Mesoblastic nephroma & $0 / 3$ \\
Bone metastasising renal tumour & $0 / 3$ \\
of childhood & $3 / 4$ \\
Rhabdoid renal tumour & $2 / 7$ \\
Clear cell renal carcinoma & $6 / 6$ \\
Normal kidneys & $3 / 3$ \\
Fetal kidneys & \\
\hline
\end{tabular}

washes in PBS being included after each step). The sections were then incubated in droplets of freshly made diaminobenzidine $(0.5 \mathrm{mg} / \mathrm{ml})$ and $\beta$-D $(+)$ glucose $(15 \mathrm{mg} / \mathrm{ml})(\mathrm{PBS})$, overnight at room temperature. They were then washed in tap water, treated with acetic acid $(1 \% \mathrm{v} / \mathrm{v}$ in distilled water), and counterstained with Mayer's haematoxylin and mounted in Canada balsalm.

Some tissue sections were stained using an indirect immunoperoxidase staining procedure as described previously. ${ }^{14}$ Sections embedded in wax were deparaffinised in two changes of xylene (five minutes each). Endogenous peroxidase was inhibited by treating sections with $0.5 \%$ hydrogen peroxide in methanol. The slides were then washed three times in PBS $0.1 \mathrm{M}, \mathrm{pH} 7 \cdot 4$, followed by a thorough rinse in tap water. Sections to be stained were treated with various dilutions $(1 / 5000-1 / 100000)$ of TammHorsfall protein monoclonal antibody for 30 minutes at room temperature, followed by extensive washing in PBS and finally a 1/40 dilution of peroxidase conjugated rabbit antimouse immunoglobulin (Dakopatts). The colour was developed using freshly prepared diaminobenzidine (DAB, Sigma) as the chromogen. After washing the sections were counterstained with haematoxylin, washed, dehydrated and mounted.

\section{Results}

The dinitrophenyl hapten staining procedure was highly specific and sensitive, giving negligible or no background staining in normal kidneys (fig 1). Furthermore, control tissue sections were entirely 


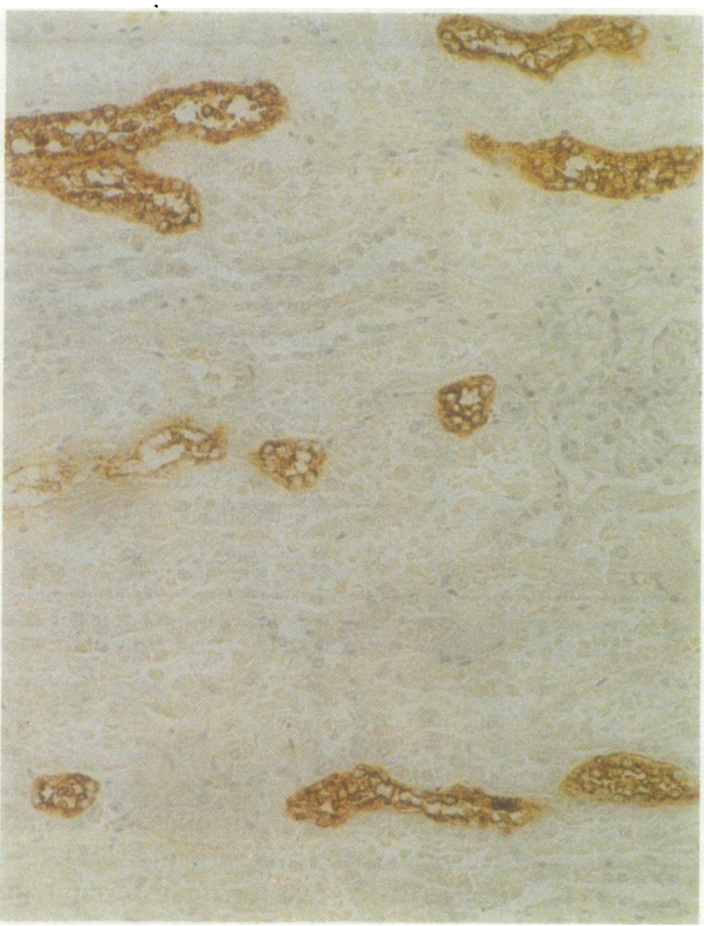

Fig 1 Normal kidney

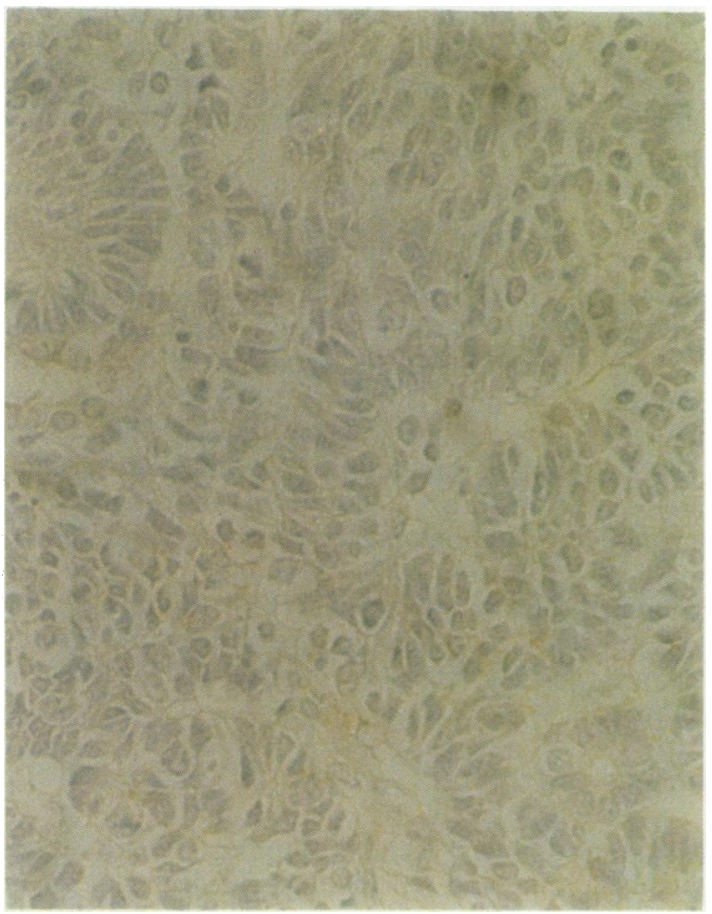

Fig 3 Wilms' tumour
Kumar, Marsden, Jasani, Kumar

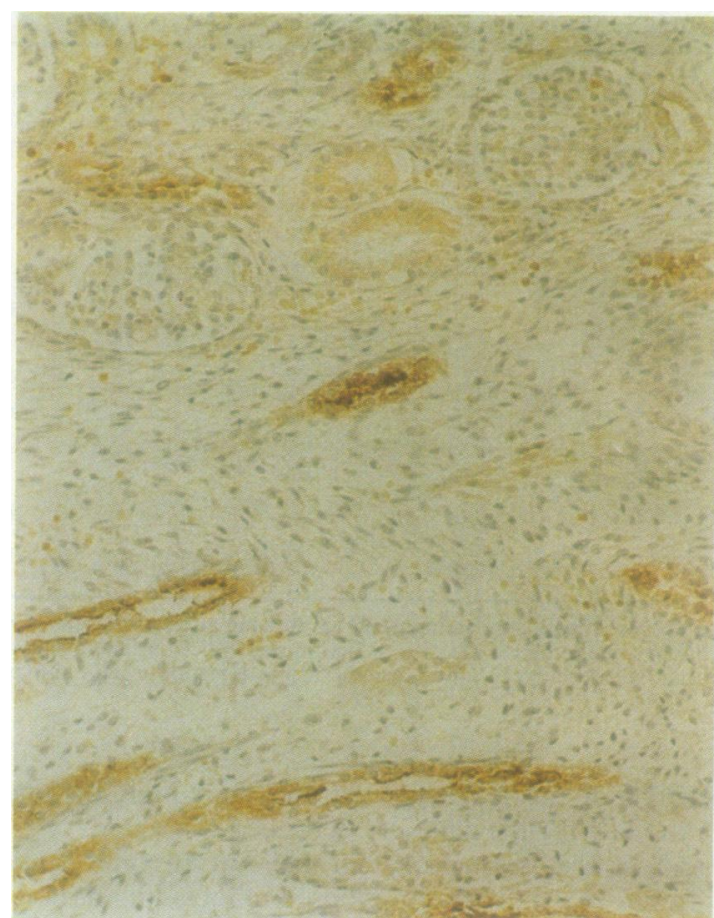

Fig 2 Fetal kidney

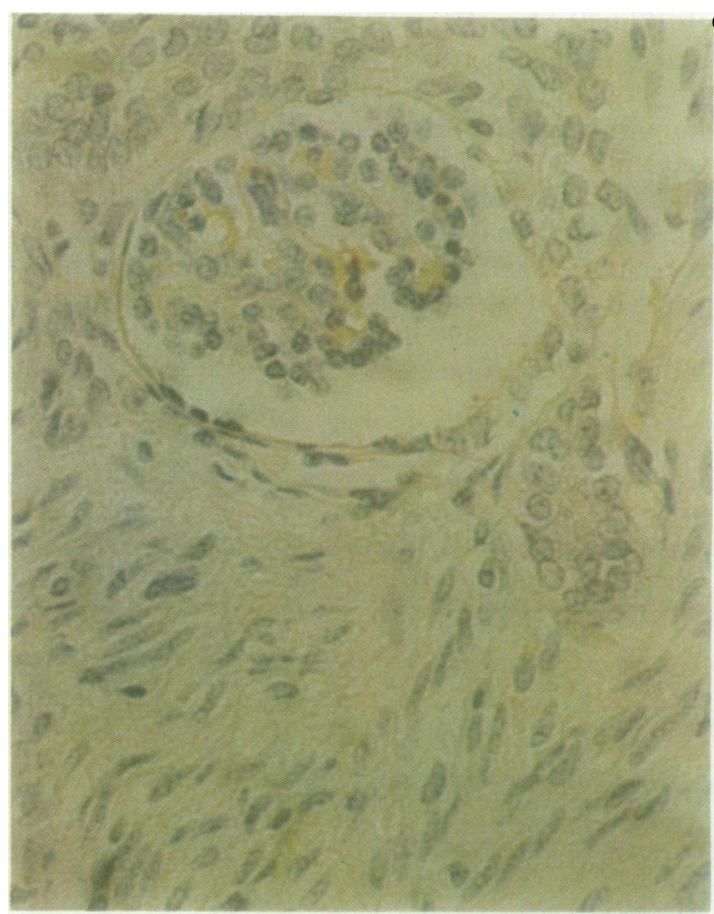

Fig 4 Mesoblastic nephroma

Figs 1-8 Immunolocalisation of Tamm-Horsfall protein in childhood renal tumours, children's normal kidneys, and human fetal kidneys. A monoclonal antibody 1/100000 dilution and dinitrophenyl hapten kit was used to stain all the tissues. 


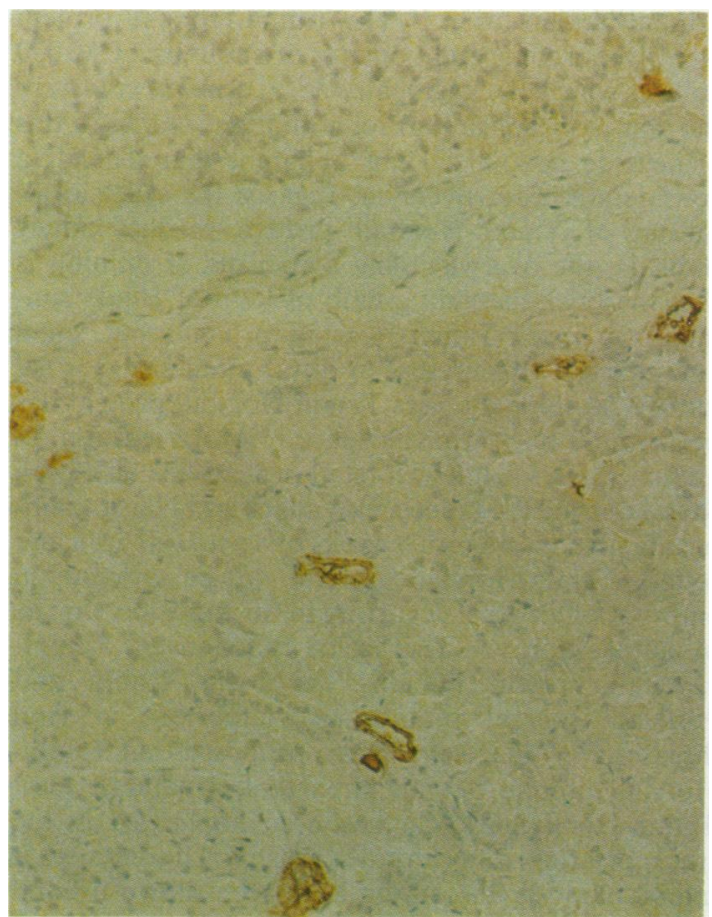

Fig 5 Renal carcinoma (left hand side) and adjacent normal looking kidney (right hand side). Note tumour cells are negative whereas strong staining is seen in the normal looking kidney.

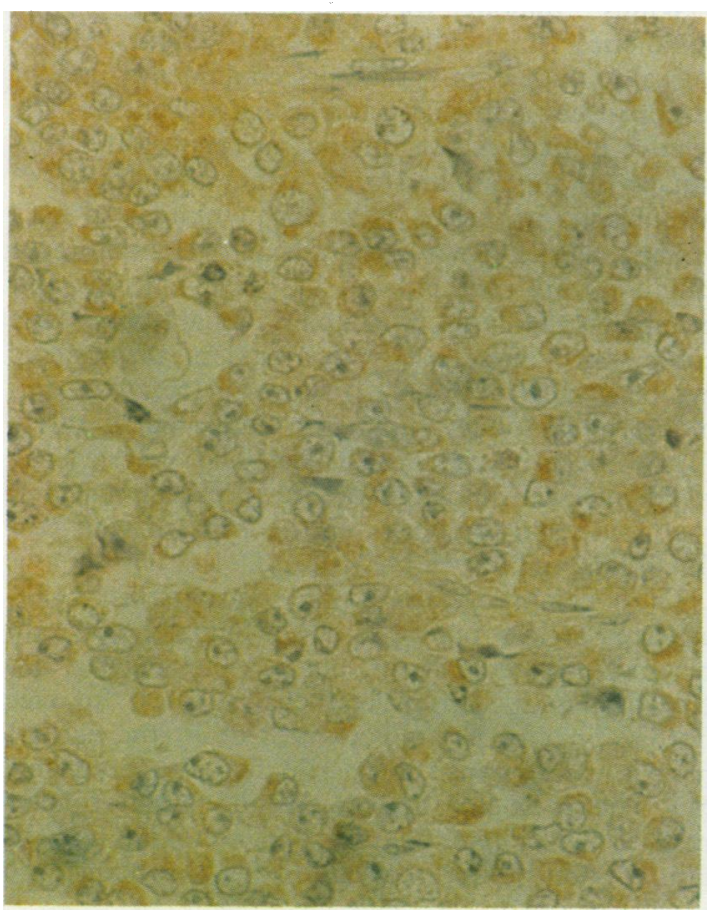

Fig 7 Rhabdoid renal tumours (low magnification)

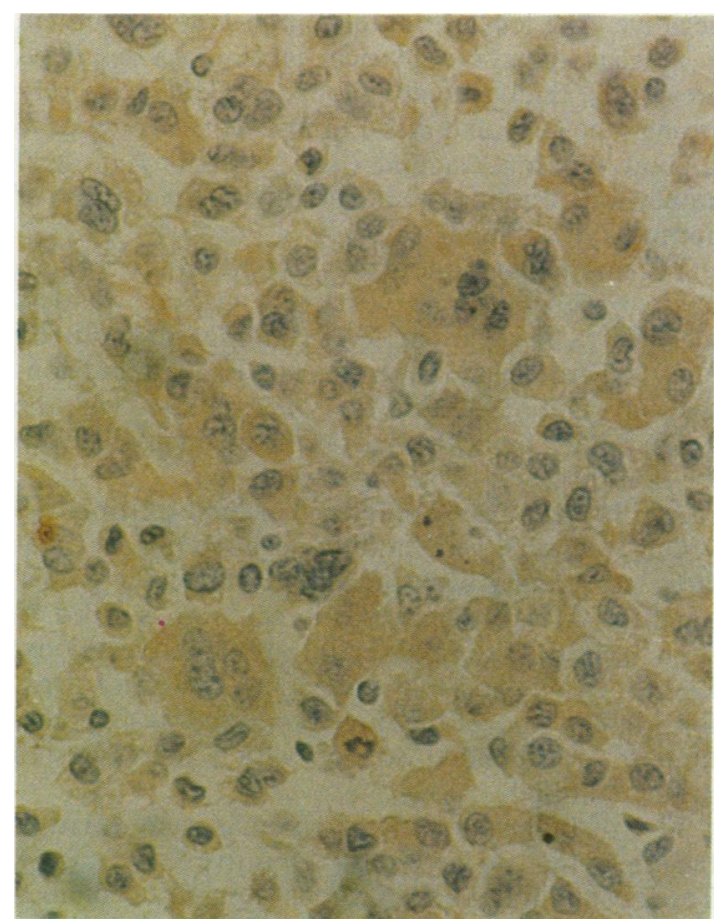

Fig 6 Renal carcinoma: one of the two renal carcinomas which were positive for Tamm-Horsfall protein.

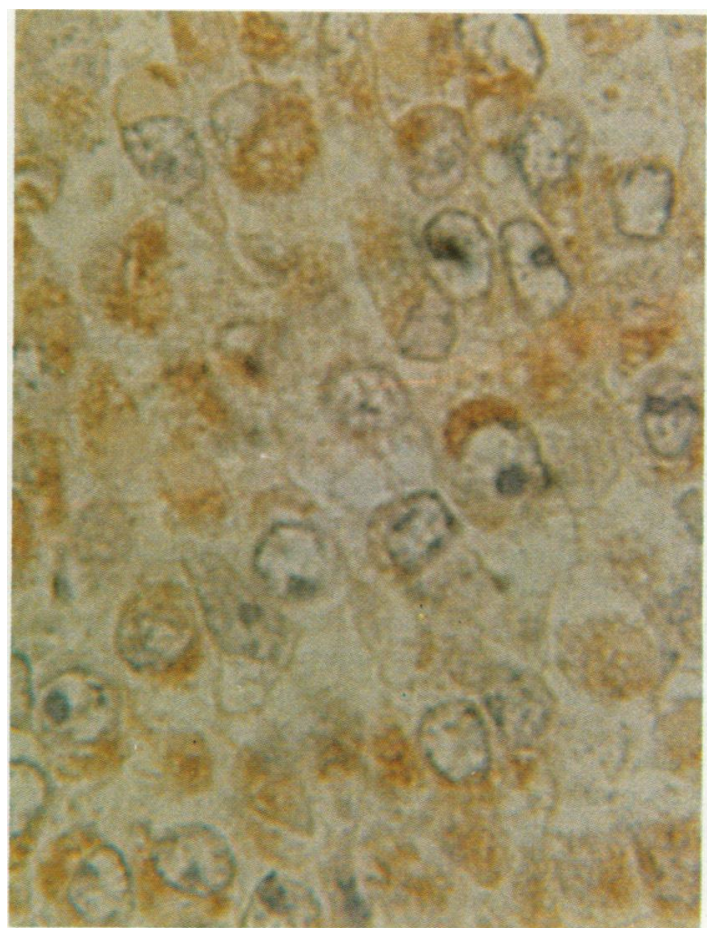

Fig 8 Same as fig 7 (high magnification). 
negative. The localisation of Tamm-Horsfall protein in normal kidneys is given in table 1. As described previously, thick ascending loops of Henle were very strongly positive and distal tubules consistently gave a good staining reaction (fig 1). Staining of fetal kidney was essentially similar in pattern to that of normal kidney (fig 2).

The indirect immunoperoxidase procedure, in contrast to the dinitrophenyl hapten method, was less sensitive as it required lower dilutions of antibody (1/20000 or less) and there was marginally more nonspecific staining. Thus the interpretation of the stained slides was a little more difficult compared with the dinitrophenyl hapten method.

All 10 well differentiated (including triphasic) Wilms' tumours were entirely negative (fig 3 ). Similarly, no staining was seen in two blastemal Wilms' tumours. All three mesoblastic nephromas failed to stain with Tamm-Horsfall protein antibody. Embedded tubular renal components were also negative (fig 4). None of the three bone metastasing renal tumour of childhood stained with Tamm-Horsfall protein antibody.

Five of the seven renal carcinomas were negative, the remaining two were weakly positive (figs 5 and 6 ). Three of the four rhabdoid renal tumours contained Tamm-Horsfall protein. The intensity of staining seen varied from weak to moderate (figs 7 and 8). None of these stained as intensely as loops of Henle in the normal kidney.

\section{Discussion}

The histogenesis of human renal tumours is obscure and controversial. ${ }^{1419}$ Grawitz proposed that renal cell carcinomas arose from adrenal rests within the kidney, ${ }^{20}$ whereas it is now generally agreed that these tumours arise from renal tubules. Nevertheless, some reports consider that they originate from proximal, others that they originate from distal tubules. ${ }^{14}$ On the other hand, the origin of Wilms' tumours has been somewhat less controversial; all workers agree with the proposal of Willis that this tumour arises from primitive metanephric blastema. ${ }^{21}$ Wallace and Nairn were the first to use an antiserum to TammHorsfall antigen to elucidate the histogenesis of renal carcinomas and Wilms' tumours. ${ }^{13}$ Unlike Wallace and Nairn, our study shows that Wilms' tumours lack this antigen though some renal carcinomas are positive. An additional important finding of the present study is that many of the rhabdoid tumours are positive for Tamm-Horsfall protein. Before discussing these results a brief account of Tamm-Horsfall protein, renal tumours, and embryogenesis of kidney will be appropriate.

In 1952 Tamm and Horsfall described a protein in normal human urine. ${ }^{22}$ The Tamm-Horsfall protein is a glycoprotein and consists of subunits of 80000 daltons which can aggregate. ${ }^{23} 24$ Cornelius et al were the first to establish that renal tubules synthesise this protein de novo. ${ }^{24}$ It is apparent that there is a considerable controversy as regards the exact localisation of Tamm-Horsfall protein in the kidney (table 1); the overwhelming consensus of opinion is that the thick ascending limb of loop of Henle contains the most Tamm-Horsfall protein, but small amounts are also present in distal tubules of normal kidney. In some diseases Tamm-Horsfall protein has been found in Bowman's space. ${ }^{11}$ More recently, in animal studies Tamm-Horsfall protein has also been iound outside the kidney. ${ }^{25}$ Wallace and Nairn examined fetal kidneys from 8 weeks of age to full term and found Tamm-Horsfall protein to be present in embryos of all ages, occurring in the same location as in adult kidney. ${ }^{8}$ The exact function of TammHorsfall protein remains unknown. Tamm and Horsfall thought that it was important in viral diseases. ${ }^{22}$ Wallace and Nairn proposed that TammHorsfall protein has an important structural role. ${ }^{8}$ Tamm-Horsfall protein has been implicated in the transportation of chloride ions. ${ }^{26}$ Diuretics that inhibit chloride absorption have been shown to bind to Tamm-Horsfall protein. ${ }^{26}$ Budi Santoso et al, however, considered that Tamm-Horsfall protein and sodium, potassium, and chlorine cotransporters were functionally unrelated. ${ }^{25}$

Wilms' tumour (or nephroblastoma) is the commonest of all childhood kidney tumours. Histologically most Wilms' tumours contain mixtures of sarcomatous, epithelial, and blastemal elements. The relative proportions of these components vary from tumour to tumour and even within a tumour. ${ }^{1928}$ Mesoblastic nephroma is a benign tumour of very young infants. ${ }^{19}$ Bone metastasising renal tumours of childhood are characterised by polygonal cells and prominent capillaries. ${ }^{27}$ Rhabdoid renal tumours are composed of large cells with abundant eosinophilic cytoplasm. ${ }^{141929}$ Renal carcinoma is the most common type of kidney tumour in adults but is rarely found in children. Prognosis for bone metastasising renal tumours of childhood, renal carcinoma, and rhabdoid renal tumour is poor compared with that for Wilms' tumour. ${ }^{14} 19$

During embryogenesis, kidney development is precipitated by the ingrowth of the ureteric bud into metanephric mesenchyme; the latter aggregates into condensates and forms epithelial tubules. In mice fibronectin and laminin are absent in the earliest morula conceptions; fibronectin becomes detectable only when mesoderm appears. Undifferentiated metanephric mesenchyme contains fibronectin but no laminin. Soon after induction of metanephric 
mesenchyme by the ureteric bud fibronectin becomes undetectable and laminin makes its first appearance. ${ }^{30-32}$ Using a panel of antibodies to fibronectin, laminin, and epithelial membrane antigen, together with peroxidase labelled lectins, we have proposed a scheme for the histogenesis of childhood renal tumours. ${ }^{1433}$

Why we found no Tamm-Horsfall protein antigen in Wilms' tumours in contrast to Wallace and Nairn ${ }^{13}$ is difficult to explain. That the difference resulted from misinterpretation or borderline staining of Wilms' tumours can be ruled out as the staining results of Wallace and Nairn are unequivocal. It is more probable that Wallace and Nairn's polyclonal antibody was not truly monospecific even after extensive absorption. Thus the Wilms' reactivity observed by Wallace and Nairn was probably an artefact. Similarly, the difference between the staining of renal carcinoma Wallace and Nairn and we observed might be attributed to a lack of antibody monospecificity.

The presence of Tamm-Horsfall protein in rhabdoid renal tumours is most intriguing. Rhabdoid renal tumours are composed of $25-40 \mu \mathrm{m}$ round cells, with abundant eosinophilic cytoplasm, and ultrastructurally concentric filamentous whorls. ${ }^{1419}$ The presence of cytokeratin and vimentin are considered to be characteristic of rhabdoid tumours. ${ }^{29}$ In a previous study we showed that most rhabdoid renal tumours were also positive for epithelial membrane antigen. ${ }^{14}$ The histogenesis of this tumour type, like the other renal neoplasms, has not been established. Unlike other childhood renal tumours, rhabdoid tumours have been described in sites outside the kidney. ${ }^{19}$ Interestingly, Tamm-Horsfall protein has also been localised outside the kidney in pancreatic acinar cells in rats, serous acinar cells of salivary gland, apical cytoplasm of mucosal cells of the jejunum, and glial cells of the human brain. ${ }^{25} 34$ It will be important to investigate more rigorously the occurrence of Tamm-Horsfall protein in organs apart from kidney and rhabdoid tumours outside the kidney in man. Such information might prove valuable in understanding the biology of rhabdoid tumours.

We are most grateful to Dr J S Hunt for providing the Tamm-Horsfall protein monoclonal antibody, Norman Thomas and Joan Ashworth for their much appreciated technical help.

\section{References}

1 Hermann G. Demonstration of the formation of urinary mucoid by the use of immunofluorescence. Verhandlungen der Deutchen Gesellschaft für Innere Medizin 1963;69:178-82.

2 Keutel HJ, King JS Jr, Boyce WH. Further studies of uromucoid in normal and stone urine. Urol Int 1964;17:324-41.

3 Cornelius CE, Mia AS, Rosenfeld A. Ruminant urolithiasis VII.
Studies on the origin of Tamm-Horsfall urinary mucoprotein and its presence in ovine calculous matrix. Invest Urol 1965;2:453-7.

4 Friedmann TH. Immunofluorescent localization of TammHorsfall mucoprotein. Experientia 1966;22:624-5.

5 McKenzie JK, McQueen EG. Immunofluorescent localization of Tamm-Horsfall mucoprotein in human kidney. J Clin Pathol 1969;22:334-9.

6 Pollak VE, Arbel C. The distribution of Tamm-Horsfall Mucoprotein (uromucoid) in the human nephron. Nephron 1969;6: 667-72.

7 Schenk EA, Schwartz RH, Lewis RA. Tamm-Horsfall mucoprotein. 1. Localisation in the kidney. Lab Invest 1971;25:92-5.

8 Wallace AC, Nairn RC. Tamm-Horsfall protein in kidneys of human embryos and foreign species. $F$ : hology 1971;3:303-10.

9 Hoyer JR, Seiler MW. Pathophysiol of Tamm-Horsfall protein. Kidney Int 1979;16:179-89.

10 Hennigar RA, Schulte BA, Spicer SS. Heterogeneous distribution of glycoconjugates in human kidney tubules. Anat Rec 1985;211:376-90.

11 Kumar S, Jasani B, Hunt JS, Moffat DB, Assacher W. A system for accurate immunolocalization of Tamm-Horsfall protein in renal biopsies. Histochem J 1985;17:1251-8.

12 Sikri KL, Foster CL, MacHugh N, Marshall RD. Localisation of Tamm-Horsfall glycoprotein in the human kidney using immunofluorescence and immunoelectron microscopical techniques. J Anat 1981;132:597-605.

13 Wallace AC, Nairn RC. Renal tubular antigens in kidney tumours. Cancer 1972;29:977-81.

14 Kumar S, Carr T, Marsden HB, Calabuig-Crespo MC. Study of childhood renal tumours using antisera to fibronectin, laminin, and epithelial membrane antigen. J Clin Pathol 1986;39:51-7.

15 Hunt JS, Peach R, McGiven AR. Monoclonal antibodies to human Tamm-Horsfall glycoprotein: preliminary characterisation of binding specificity. In: Abstracts of the IX International Congress of Nephrology. Los Angeles: 1984:243A

16 Hunt JS, Peach R, McGiven AR. Monoclonal antibodies to human Tamm-Horsfall glycoprotein (THP): characterisation and use for detection of THP in biological fluids. NZ Med J 1985;98:16.

17 Hunt JS, McGiven AR, Groufsky A, Lynn KL, Taylor MC. Affinity purified antibodies of defined specificity for use in a solid-phase microplate radioimmunoassay of human TammHorsfall glycoprotein in urine. Biochem $J$ 1985;227:957-63.

18 Jasani B, Wynford-Thomas D, Williams ED. Use of monoclonal antihapten antibodies for immunolocalisation of tissue antigens. J Clin Pathol 1981;34:1000-2.

19 Gonzalez-Crussi R. Wilms' tumour (nephroblastoma) and related renal neoplasms of childhood. Florida: CRC Press Inc, 1984.

20 Grawitz P. Die Sogennanten Lipome der Niere. Virchows Arch (Pathol Anat) 1883;93:39-63.

21 Willis RA. Pathology of Tumours. 3rd ed. London: Butterworths 1960.

22 Tamm I, Horsfall FL. A mucoprotein derived from human urine which reacts with influenza, mumps and Newcastle disease viruses. $J$ Exp Med 1952;95:71-7.

23 Fletcher AP, Neuberger A, Ratcliffe WA. Tamm-Horsfall urinary glycoprotein. The chemical composition. Biochem J 1970; 120:417-24.

24 Fletcher AP, Neuberger A, Ratcliffe WA. Tamm-Horsfall urinary glycoprotein. The subunit structure. Biochem J 1970;120: 425-32.

25 Budi Santoso AW, Scott DM, Kinne R. Localization of Tamm-Horsfall protein in chloride transporting epithelia: lack of correlation with the $\mathrm{Na}, \mathrm{K}, \mathrm{Cl}$ cotransporter. Eur J Cell Biol 1987;43:104-9.

26 Richet G. The mechanism of action of some loop-acting diuretics-Role of binding to Tamm-Horsfall protein. Clin Nephrol 1983;19(suppl 1):42-4.

27 Marsden HB, Lawler W, Kumar P. Bone-metastasizing renal 
tumours of childhood. Cancer 1978;42:1922-8.

28 Beckwith JB, Palmer NF. Histopathology and prognosis of Wilms' tumour: results from the first national Wilms' tumour study. Cancer 1978;41:1937-48.

29 Vogel AM, Gown AM, Caughlan J, Hass JE, Beckwith JB. Rhabdoid tumours of the kidney contain mesenchymal specific and epithelial specific intermediate filament proteins. Lab Invest 1984;50:232-8.

30 Ekblom P. Basement membrane proteins and growth factors in kidney differentiation. In: Trelstad RL, ed. The role of extracellular matrix in development. New York: Alan R Liss, 1984:173-206.

31 Sariola H, Ekblom P, Rapola J, Vaheri A, Timpl R. Extracellular matrix and epithelial differentiation of Wilms' tumour. Am J Pathol 1985;118:96-107.
32 Sariola H. Angiogenesis of the kidney. Helsinki, Finland. University of Finland, 1985:1-40 (Thesis.)

33 Kumar S, Carr T, Marsden HB, Morris-Jones PH. Study of childhood renal tumours using peroxidase conjugated lectins. $J$ Clin Pathol 1986;39:736-41.

34 Zalc BC, Collet A, Monge M, et al. Tamm-Horsfall protein, a kidney marker is expressed on brain sulfogalactosylceramidepositive astroglial structures. Brain Res 1984;291:182-7.

Requests for reprints to: Dr S Kumar, Paediatric Oncology Laboratory, Christie Hospital and Holt Radium Institute, Wilmslow Road, Withington, Manchester M20 9BX, England. 